\title{
Correlation of the expression of miR-146a in peripheral blood mononuclear cells of patients with ankylosing spondylitis and inflammatory factors
}

\author{
CHENGJUN WEI $^{1}$, HONGXIA ZHANG ${ }^{1}$, CHENGHONG WEI $^{2}$ and YOUYAN MAO ${ }^{3}$ \\ ${ }^{1}$ Department of Laboratory Medicine, Weifang People's Hospital; ${ }^{2}$ Department of Laboratory Medicine, \\ Weifang Traditional Chinese Hospital; ${ }^{3}$ Department of General Surgery, \\ Weifang People's Hospital, Weifang, Shandong 261041, P.R. China
}

Received June 7, 2017; Accepted September 14, 2017

DOI: $10.3892 / \mathrm{etm} .2017 .5155$

\begin{abstract}
We investigated the expression of miR-146a in peripheral blood mononuclear cell (PBMC) of patients with ankylosing spondylitis (AS) and its correlation with inflammatory factors to explore the clinical significance. In total 45 patients with AS were selected at the Weifang People's Hospital from June, 2014 to January, 2016. At the same time, 30 healthy volunteers were also selected to serve as control group. Expression level of miR-146a in PBMC cells of patients in each group was detected by quantitative real-time-polymerase chain reaction (qRT-PCR). Levels of tumor necrosis factor- $\alpha$ (TNF- $\alpha$ ), interleukin-1 $\beta$ (IL-1 $\beta$ ) and IL-6 in serum and the supernatant of culture medium of PBMC derived from each group were detected by enzyme-linked immunosorbent assay (ELISA). Correlations between expression level of miR-146a and serum inflammatory factors, and clinical indicators were analyzed. Clinical indicators included bath ankylosing spondylitis disease activity index (BASDAI), C-reactive protein (CRP), erythrocyte sedimentation rate (ESR) and duration of morning stiffness. Expression level of miR-146a in PBMC of AS patients was significantly higher than that of healthy control $(\mathrm{P}<0.01)$; levels of TNF- $\alpha$, IL- $1 \beta$ and IL- 6 in serum and the supernatant of culture medium of PBMC derived from AS patients were significant compared to those of control group $(\mathrm{P}<0.01)$; expression of miR-146a in PBMC of patients with AS was positively correlated with the levels of TNF- $\alpha$, IL-1 $\beta$ and IL-6 in serum $(r=0.632, \mathrm{P}<0.01 ; \mathrm{r}=0.574, \mathrm{P}<0.01 ; \mathrm{r}=0.483$, $\mathrm{P}<0.01$ ). In addition, expression level of miR-146a in PBMC of patients with AS was positively correlated with BASDAI,
\end{abstract}

Correspondence to: Dr Youyan Mao, Department of General Surgery, Weifang People's Hospital, 151 Guangwen Street, Kuiwen, Weifang, Shandong 261041, P.R. China

E-mail: nvi8sa@163.com

Key words: ankylosing spondylitis, peripheral blood mononuclear cells, miR-146a, inflammatory factor
ESR, CRP and duration of morning stiffness $(r=0.551, P<0.01$; $r=0.738, \mathrm{P}<0.01 ; \mathrm{r}=0.685, \mathrm{P}<0.01 ; \mathrm{r}=0.497, \mathrm{P}<0.01)$. Expression level of miR-146a in PBMC of AS patients was significantly increased and the expression level was positively correlated with the levels of TNF- $\alpha$, IL-1 $\beta$ and IL-6 in serum $(\mathrm{P}<0.05)$. In addition, expression level of miR-146a in PBMC of AS patients was also positively correlated with BASDAI, ESR, CRP and duration of morning stiffness. Those results suggest that miR-146a may be involved in the pathogenesis of AS, and the expression level of miR-146a in PBMC cells may be helpful for diagnosis of AS and judgment of disease activity.

\section{Introduction}

As an inflammatory spine and joint disease, pathogenesis of ankylosing spondylitis (AS) is mainly correlated with human leukocyte antigen B27 (HLA-B27). Inflammatory factors can invade synovial joints, articular cartilage, tendons, ligaments and attachment points of ligament to cause fibrous and bony rigidity $(1,2)$. With the high morbidity, AS seriously affects human health. However, etiology and pathogenesis of AS are very complex, and studies have shown that the occurrence of AS is closely correlated with genetic factors, inflammatory factors, autoimmune disorders and other factors (3).

MicroRNAs (miRNAs) are endogenous non-coding single-stranded small molecule RNAs with a length of 18-25 nucleotides. miRNAs plays pivotal roles in cell development, proliferation, differentiation and apoptosis, and carcinogenic process through the regulation of gene expression at post-transcriptional level, and expression of miRNAs is closely correlated with the development of various human diseases (4). Studies have shown that human genome encodes $>1,000$ miRNAs, and these miRNAs can regulate the expression of $60 \%$ of all protein-encoding genes (5). miRNAs can act on 3'-untranslated region of target mRNA, which in turn leads to the silencing of the target gene (6).

Studies have shown that miRNAs play important roles in the development and progression of rheumatic diseases, and the most studied miRNA is miR-146a (7). It has been shown that Toll-like receptor ligands such as lipopolysaccharide, lipoprotein and inflammatory factors such as tumor 
necrosis factor- $\alpha$ (TNF- $\alpha)$ and interleukin-1 $1 \beta$ (IL-1 $\beta$ ) can increase the expression of miR-146a by activating nuclear factor- $\mathrm{\kappa B}$ (NF- $\mathrm{\kappa B}$ ) activity, while overexpression of miR-146a can inhibit the activity of NF-kB pathway by inhibiting the expression of TNF receptor associated factor 6 (TRAF-6) and interleukin 1 receptor-associated kinase-1 (IRAK-1) $(8,9)$. Studies have shown that NF- $\mathrm{\kappa B}$ can affect the production of TNF- $\alpha$, IL-1 $\beta$ and IL-6 (10), so we speculate that miR-146a can affect the levels of inflammatory factors in patients with AS through NF- $\kappa$ B pathway. In this study, expression level of miR-146a in peripheral blood mononuclear cell (PBMC) and levels of TNF- $\alpha$, IL-1 $\beta$ and IL-6 in serum of AS patients were detected. In addition, the correlation between expression of miR-146a and levels of TNF- $\alpha$, IL-1 $\beta$ and IL- 6 , and clinical indicators including bath ankylosing spondylitis disease activity index (BASDAI), C-reactive protein (CRP), erythrocyte sedimentation rate (ESR) and duration morning stiffness were analyzed.

\section{Materials and methods}

Materials. Forty-five patients with AS who were admitted by the Department of Rheumatology of Weifang Hospital were selected from June, 2014 to January, 2016. Among the patients, there were 33 males and 12 females with an average age of $27.42 \pm 6.85$ years. All patients with AS were diagnosed according to the New York standard established by American College of Rheumatology in 1984 (11), all patients were HLA-B27 positive. Exclusion criteria: Patients received intra-articular and glucocorticoid treatment before admission, patients suffering from severe heart, brain, kidney and other vital organs dysfunction and systemic disease, pregnant and lactating women. A total of 30 normal healthy people who received physical examination in Weifang Hospital were selected as normal control group. Control group included 21 males and 9 females with an average age of $26.73 \pm 5.36$ years. There was no significant difference in gender and age between AS group and normal control group. Clinical parameters of AS patients including BASDAI, ESR, CRP and duration of morning stiffness were collected. Sample collections were approved by the Ethics Committee of Weifang People's Hospital. All participants signed informed consent.

RPMI-1640 medium and fetal bovine serum (FBS) (HyClone Laboratories, Logan, UT, USA); Ficoll paque plus lymphocyte isolation solution (GE Healthcare, Bethesda, MD, USA); RNA extraction kit (Invitrogen, Carlsbad, CA, USA); primer synthesis, reverse transcription kit, and quantitative real-time PCR (qRT-PCR) kit (Takara, Dalian, China); IL-1 $\beta$, IL- 6 and TNF- $\alpha$ enzyme-linked immunosorbent assay (ELISA) kits (Beyotime Institute, Nantong, China) were used.

Isolation of PBMC from patients and cell culture. Fasting venous blood $(5 \mathrm{ml})$ was extracted from AS patients and healthy control in the morning and ethylenediaminetetraacetic acid (EDTA) was added for anticoagulation. PBMCs were isolated using Ficoll-Paque Plus lymphocyte isolation solution. PBMCs were cultured with RPMI-1640 medium containing $10 \%$ autologous serum in an incubator $\left(37^{\circ} \mathrm{C}, 5 \% \mathrm{CO}_{2}\right)$ for $2 \mathrm{~h}$. After that, cells were washed and suspended cells were removed to obtain adherent cells (PBMCs). Culture medium
Table I. Primers used for qRT-PCR.

\begin{tabular}{ll}
\hline Genes & \multicolumn{1}{c}{ Primer sequences } \\
\hline miR-146a & F: 5'-TGAGAACTGAATTCCATGGGTT-3' \\
& R: 5'-GCTGTCAACGATACGCTACGTAACG-3' \\
U6 & F: 5'-GCTTCGGCAGCACATATACTAAAAT-3' \\
& R: 5'-CGCTTCACGAATTTGCGTGTCAT-3' \\
\hline
\end{tabular}

F, forward; R, reverse.

Table II. General information of subjects.

\begin{tabular}{lccc}
\hline Characteristics & $\begin{array}{c}\text { AS group } \\
(\mathrm{n}=45)\end{array}$ & $\begin{array}{c}\text { Normal } \\
\text { control group }\end{array}$ & P-value \\
\hline Sex (male/female) & $33 / 12$ & $21 / 9$ & $\mathrm{P}>0.05$ \\
Age (years) & $27.42 \pm 6.85$ & $26.73 \pm 5.36$ & $\mathrm{P}>0.05$ \\
BASDAI score & $4.97 \pm 1.39$ & $\mathrm{NA}$ & $\mathrm{NA}$ \\
ESR (mm/h) & $21.08 \pm 19.33$ & $\mathrm{NA}$ & $\mathrm{NA}$ \\
CRP (mg/l) & $17.35 \pm 15.76$ & $\mathrm{NA}$ & $\mathrm{NA}$ \\
$\begin{array}{l}\text { Duration of morning } \\
\text { stiffness (min) }\end{array}$ & $30.58 \pm 27.57$ & $\mathrm{NA}$ & $\mathrm{NA}$ \\
\hline
\end{tabular}

BASDAI, bath ankylosing spondylitis disease activity index; NA, not applicable; ESR, erythrocyte sedimentation rate; CRP, C-reactive protein.

was replaced every $24 \mathrm{~h}$, and subculture was performed when cell fusion was reached.

qRT-PCR to detect the expression of miR-146a in PBMC. PBMCs were collected and total RNA was extracted using RNA extraction kit according to the instruction. Concentration and purity of total RNA were measured using UV-Vis spectrophotometer (Hitachi, Tokyo, Japan) and only samples with a ratio of A260/A280 between 1.8 and 2.0 were used. Reverse transcription was then performed according to the instructions of reverse transcription kit to synthesize cDNA. qRT-PCR was performed according to the instruction of qRT-PCR kit using cDNA as template and U6 RNA as endogenous control. The primers for miR-146a and U6 are listed in Table I. Reaction conditions were $95^{\circ} \mathrm{C}$ for $10 \mathrm{~min}$, followed by 40 cycles of $95^{\circ} \mathrm{C}$ for $15 \mathrm{sec}$ and $60^{\circ} \mathrm{C}$ for $1 \mathrm{~min}$. $\mathrm{Ct}$ values were processed using $2^{-\mathrm{ACt}}$ method according to the following formula: $\Delta \mathrm{Ct}$ (target gene) $=\mathrm{Ct}$ (target gene $)-\mathrm{Ct}$ (control gene).

ELISA method to detect the levels of IL-1 $\beta, I L-6$ and TNF- $\alpha$ in supernatant of PBMC medium and serum. PBMCs were collected at logarithmic growth phase, and $2 \mathrm{ml}$ $\left(2 \times 10^{5}\right.$ cells $\left./ \mathrm{ml}\right)$ PBMC cell suspension was transferred to a 6-well plate, followed by incubation for $24 \mathrm{~h}$. Supernatant (50 $\mu \mathrm{l})$ of culture medium was collected to measure the levels of IL- $1 \beta$, IL- 6 and TNF- $\alpha$ using ELISA according to the instructions. Fasting venous blood $(5 \mathrm{ml})$ was extracted from 


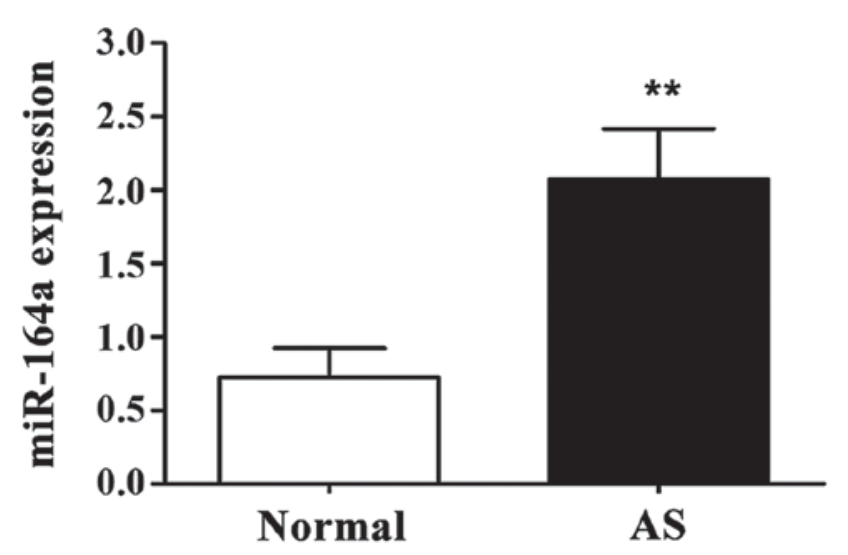

Figure 1. Expression level of miR-146a in peripheral blood mononuclear cell (PBMC). Compared with control group, expression level of miR-146a in PBMC of ankylosing spondylitis (AS) group was significantly increased. ${ }^{* *} \mathrm{P}<0.01$ compared with normal control group.

AS patients and healthy controls in the morning. After water bath at $37^{\circ} \mathrm{C}$ for $10 \mathrm{~min}$, blood samples were centrifuged to collect serum. Serum sample were stored at $-20^{\circ} \mathrm{C}$ before use. Serum contents of IL-1 $\beta$, IL- 6 and TNF- $\alpha$ were measured using ELISA according to the instructions.

Statistical analysis. Data were analyzed using SPSS 17.0 software (IBM Corp., Armonk, NY, USA). Measurement data were expressed as mean \pm standard deviation, and comparisons between two groups were performed using t-test. Comparisons of count data between two groups were performed using $\chi^{2}$. Pearson's correlation analysis was used to analyze the correlation between variables. $\mathrm{P}<0.05$ was considered to be statistically significant.

\section{Results}

Comparison of general information between AS disease group and control group. In this study, 45 patients with AS were collected, including 33 males and 12 females with an average age of $27.42 \pm 6.85$ years. There were 30 healthy people in healthy control group, including 21 males and 9 females with an average age of $26.73 \pm 5.36$ years. There was no significant difference in gender and age between the two groups $(\mathrm{P}>0.05)$ General information, BASDAI score, ESR, CRP and duration of morning stiffness of AS patients and normal controls are listed in Table II.

Expression level of miR-146a in PBMC detected by qRT-PCR. As shown in Fig. 1, expression level of miR-146a in PBMC of AS group was significantly higher than that of normal control group $(\mathrm{P}<0.01)$.

Levels of TNF- $\alpha, I L-1 \beta$ and IL-6 in supernatant of PBMC culture medium. Levels of TNF- $\alpha$, IL-1 $\beta$ and IL-6 in supernatant of PBMCs derived from AS patients were significantly higher than those in normal control group $(\mathrm{P}<0.01)$ (Fig. 2).

Levels of TNF- $\alpha, I L-1 \beta$ and IL-6 in serum. Levels of TNF- $\alpha$, IL- $1 \beta$ and IL- 6 in serum of AS patients were significantly higher than those of healthy controls $(\mathrm{P}<0.01)$ (Fig. 3).
Table III. Correlation between miR-146a expression and serum inflammatory factors in patients with AS.

\begin{tabular}{lccc}
$\begin{array}{l}\text { Serum } \\
\text { inflammatory } \\
\text { factors }\end{array}$ & TNF- $\alpha$ & IL-1 $\beta$ & IL-6 \\
\hline $\begin{array}{l}\text { miR-146a } \\
\text { P-value }\end{array}$ & $\mathrm{r}=0.632$ & $\mathrm{r}=0.574$ & $\mathrm{r}=0.483$ \\
\hline
\end{tabular}

TNF- $\alpha$, tumor necrosis factor- $\alpha$; IL, interleukin.

Table IV. Correlation between miR-146a expression and clinical indicators of AS patients.

\begin{tabular}{lcccc}
\hline $\begin{array}{l}\text { Clinical } \\
\text { indicators }\end{array}$ & BASDAI & ESR & CRP & $\begin{array}{c}\text { Duration of } \\
\text { morning stiffness }\end{array}$ \\
\hline miR-146a & $\mathrm{r}=0.551$ & $\mathrm{r}=0.738$ & $\mathrm{r}=0.685$ & $\mathrm{r}=0.497$ \\
$\mathrm{P}$-value & $\mathrm{P}<0.01$ & $\mathrm{P}<0.01$ & $\mathrm{P}<0.01$ & $\mathrm{P}<0.01$ \\
\hline
\end{tabular}

BASDAI, bath ankylosing spondylitis disease activity index; ESR, erythrocyte sedimentation rate; CRP, C-reactive protein; AS, ankylosing spondylitis.

Correlation between miR-146a expression and serum inflammatory factors in patients with AS. Correlation between miR-146a expression and levels of TNF- $\alpha$, IL-1 $\beta$ and IL-6 in serum were analyzed by Pearson's correlation analysis. As shown in Table III, relative expression levels of miR-164a in PBMCs of AS patients were positively correlated with the levels of TNF- $\alpha$, IL-1 $\beta$ and IL- 6 in serum $(\mathrm{P}<0.01)$.

Correlation between miR-146a expression and clinical indicators of AS patients. Pearson's correlation analysis (Table IV) showed that relative expression level of miR-164a in PBMC of AS patients was positively correlated with BASDAI, ESR, $\mathrm{CRP}$ and duration of morning stiffness $(\mathrm{P}<0.01)$.

\section{Discussion}

AS is a kind of chronic progressive inflammatory disease with the main clinical manifestations of waist, back, neck, buttocks and hip pain, joint swelling and pain, difficulties in movement and eye, lung, kidney and other organ damage, seriously affecting the life quality of patients (12-14).

miRNAs are noncoding small RNAs that can regulate gene expression. Mature miRNA binds to proteins to form RNA-induced silencing complexes, which can inhibit mRNA translation to reduce translation under imperfect base pairing. Under perfect base pairing, RNA-induced silencing complexes can cause mRNA degradation. Therefore, miRNA can regulate a series of physiological processes in cells by inhibiting mRNA degradation or cutting mRNA (15). miR-146 family has two members: miR-146a and miR-146b. miR-146a can specifically inhibit the expression of bridging molecules (such as TRAF-6 and IRAK-1) between Toll-like receptor and NF- $\kappa$ B, so as to indirectly inhibit the activity of $N F-\kappa B$ and reduce 

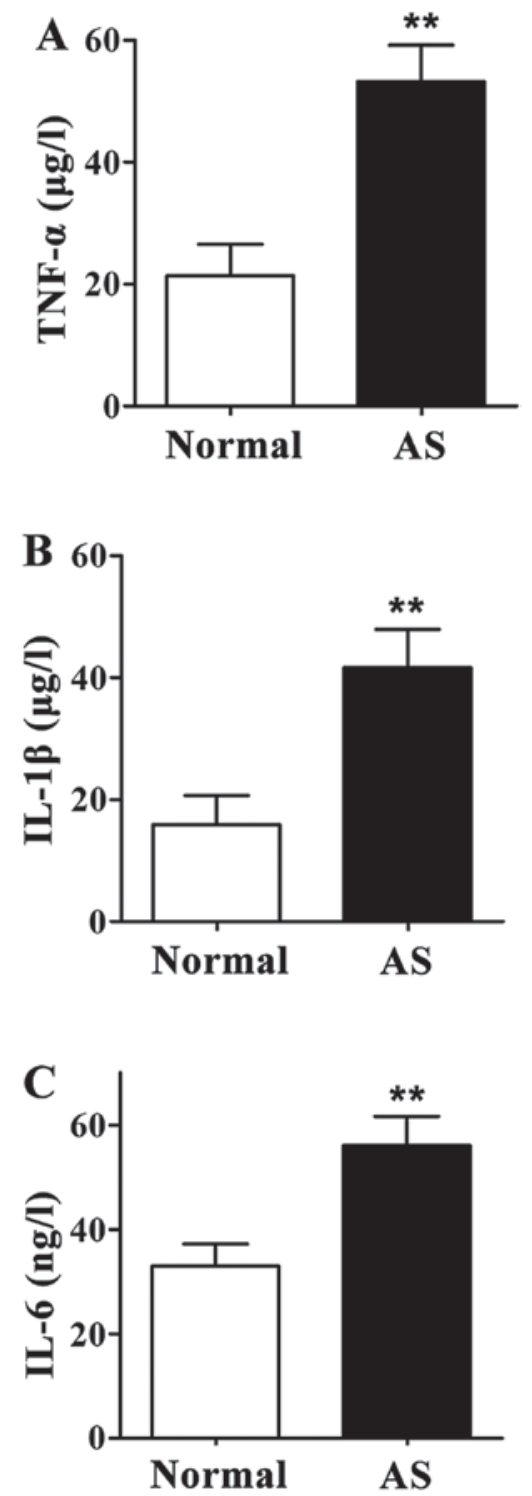

Figure 2. Levels of tumor necrosis factor- $\alpha$ (TNF- $\alpha$ ), interleukin-1 $\beta$ (IL-1 $\beta$ ) and IL-6 in supernatant of peripheral blood mononuclear cell (PBMC) culture medium detected by enzyme-linked immunosorbent assay (ELISA). Compared with the normal control group, levels of TNF- $\alpha$, IL-1 $\beta$ and IL-6 in supernatant of PBMC culture medium were significantly increased in ankylosing spondylitis (AS) patients. (A) Content of TNF- $\alpha$ in supernatant of PBMC culture medium. (B) Content of IL- $1 \beta$ in supernatant of PBMC culture medium. (C) IL- 6 content in supernatant of PBMC culture medium. ${ }^{* *} \mathrm{P}<0.01$ compared with normal control group.

the production of IL-1 $\beta$, IL- 6 and other inflammatory factors. miR-146 plays a key role in the pathogenesis of systemic rheumatic diseases such as systemic lupus erythematosus and systemic scleroderma $(16,17)$. Studies have shown that the activation of NF-kB pathway can lead to the production of a huge amount of inflammatory factors such as TNF- $\alpha$, IL-1 $\beta$ and IL-6, which may be associated with the high expression level of miR-146a (18).

As common inflammatory factors, TNF- $\alpha$, IL-1 $1 \beta$ and IL-6 have anti-infection, anti-tumor, immune regulation and other biological effects. Under disease conditions, increased levels of inflammatory factors can further cause tissue damage and exacerbations $(19,20)$. As an autoimmune inflammatory disease, the development of AS is closely related with
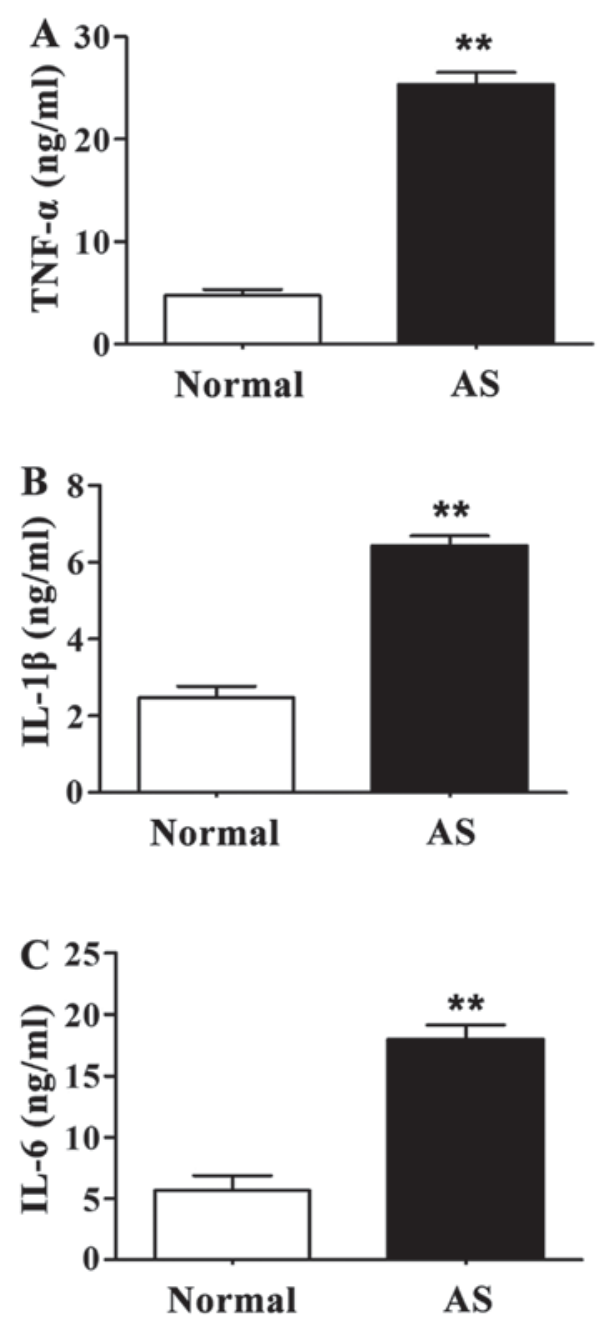

Figure 3. Serum levels of tumor necrosis factor- $\alpha$ (TNF- $\alpha)$, interleukin-1 $\beta$ (IL-1 $\beta$ ) and IL- 6 detected by enzyme-linked immunosorbent assay (ELISA). Compared with the normal control group, levels of TNF- $\alpha$, IL-1 $\beta$ and IL-6 in serum of ankylosing spondylitis (AS) patients were significantly increased. (A) Content of TNF- $\alpha$ in serum. (B) Content of IL-1 $\beta$ in serum. (C) Content of IL-6 in serum. ${ }^{* *} \mathrm{P}<0.01$ compared with normal control group.

Inflammatory factors. It has been reported that TNF- $\alpha$, IL-1 $\beta$ and IL-6 are involved in the pathogenesis of AS $(21,22)$.

Results of this study showed that expression level of miR-146a in PBMCs of AS patients was significantly higher than that of healthy adults. In addition, levels of TNF- $\alpha$, IL-1 $\beta$ and IL-6 in serum and supernatant of PBMC culture medium were significantly higher in healthy AS patients than in healthy adults, and the expression level of miR-146a was positively correlated with levels of TNF- $\alpha$, IL- $1 \beta$ and IL- 6 . In addition, BASDAI, ESR, CRP and duration of morning stiffness were the most common indicators of AS. This study showed that expression level of miR-146a was positively correlated with BASDAI, ESR, CRP and duration of morning stiffness in AS patients. These results suggest that miR-146a may play an important role in the development and progression of AS disease.

In conclusion, expression level of miR-146a in PBMC of AS patients was positively correlated with the levels of TNF- $\alpha$, IL-1 $\beta$ and IL-6, and clinical indicators of patients, suggesting that miR-146a may be involved in AS by influencing the 
expression of inflammatory factors. Therefore, miR-146a may provide a new direction for AS diagnosis and treatment.

\section{References}

1. Braun J and Sieper J: The sacroiliac joint in the spondyloarthropathies. Curr Opin Rheumatol 8: 275-287, 1996.

2. Braun J, Bollow M, Remlinger G, Eggens U, Rudwaleit M, Distler A and Sieper J: Prevalence of spondylarthropathies in HLA-B27 positive and negative blood donors. Arthritis Rheum 41: 58-67, 1998

3. Xiang YJ and Dai SM: Prevalence of rheumatic diseases and disability in China. Rheumatol Int 29: 481-490, 2009.

4. Bartel DP: MicroRNAs: Target recognition and regulatory functions. Cell 136: 215-233, 2009.

5. Siomi H and Siomi MC: On the road to reading the RNA-interference code. Nature 457: 396-404, 2009.

6. Panera N, Gnani D, Crudele A, Ceccarelli S, Nobili V and Alisi A: MicroRNAs as controlled systems and controllers in non-alcoholic fatty liver disease. World J Gastroenterol 20 15079-15086, 2014.

7. Taganov KD, Boldin MP, Chang KJ and Baltimore D: NF-kappaB-dependent induction of microRNA miR-146, an inhibitor targeted to signaling proteins of innate immune responses. Proc Natl Acad Sci USA 103: 12481-12486, 2006

8. Bhaumik D, Scott GK, Schokrpur S, Patil CK, Campisi J and Benz CC: Expression of microRNA-146 suppresses NF-kappaB activity with reduction of metastatic potential in breast cancer cells. Oncogene 27: 5643-5647, 2008

9. Pedersen I and David M: MicroRNAs in the immune response. Cytokine 43: 391-394, 2008.

10. Liu Z, Xiao B, Tang B, Li B, Li N, Zhu E, Guo G, Gu J, Zhuang Y, Liu X, et al: Up-regulated microRNA-146a negatively modulate Helicobacter pylori-induced inflammatory response in human gastric epithelial cells. Microbes Infect 12: 854-863, 2010.

11. Van der Linden S, Valkenburg HA and Cats A: Evaluation of diagnostic criteria for ankylosing spondylitis. A proposal for modification of the New York criteria. Arthritis Rheum 27: 361-368, 1984.
12. Han GW, Zeng LW, Liang CX, Cheng BL, Yu BS, Li HM,Zeng FF and Liu SY: Serum levels of IL-33 is increased in patients with ankylosing spondylitis. Clin Rheumatol 30: 1583-1588, 2011.

13. Fan D, Ding N, Yang T, Wu S, Liu S, Liu L, Hu Y, Duan Z, Xia G, Xu S, et al: Single nucleotide polymorphisms of the interleukin-33 (IL-33) gene are associated with ankylosing spondylitis in Chinese individuals: A case-control pilot study. Scand J Rheumatol 43: 374-379, 2014

14. Ciccia F, Alessandro R, Rizzo A, Accardo-Palumbo A, Raimondo S, Raiata F, Guggino G, Giardina A, De Leo G, Sireci G, et al: Macrophage phenotype in the subclinical gut inflammation of patients with ankylosing spondylitis. Rheumatology (Oxford) 53: 104-113, 2014.

15. Denli AM, Tops BB, Plasterk RH, Ketting RF and Hannon GJ: Processing of primary microRNAs by the microprocessor complex. Nature 432: 231-235, 2004

16. Zilahi E, Tarr T, Papp G, Griger Z, Sipka S and Zeher M: Increased microRNA-146a/b, TRAF6 gene and decreased IRAK1 gene expressions in the peripheral mononuclear cells of patients with Sjögren's syndrome. Immunol Lett 141: 165-168, 2011.

17. Rostom S, Dougados M and Gossec L: New tools for diagnosing spondyloarthropathy. Joint Bone Spine 77: 108-114, 2010.

18. Gregory RI, Yan KP, Amuthan G, Chendrimada T, Doratotaj B, Cooch N and Shiekhattar R: The Microprocessor complex mediates the genesis of microRNAs. Nature 432: 235-240, 2004.

19. Feldmann M, Brennan FM and Maini RN: Role of cytokines in rheumatoid arthritis. Annu Rev Immunol 14: 397-440, 1996.

20. Butler DM, Maini RN, Feldmann M and Brennan FM: Modulation of proinflammatory cytokine release in rheumatoid synovial membrane cell cultures. Comparison of monoclonal anti TNF-alpha antibody with the interleukin-1 receptor antagonist. Eur Cytokine Netw 6: 225-230, 1995.

21. Park MC, Chung SJ, Park YB and Lee SK: Pro-inflammatory effect of leptin on peripheral blood mononuclear cells of patients with ankylosing spondylitis. Joint Bone Spine 76: 170-175, 2009

22. Claudepierre P, Rymer JC, Authier FJ, Allanore Y, Larget-Piet B, Gherardi R and Chevalier X: A relationship between TGF-beta 1 or IL-6 plasm Levels and clinical features of ankylosing spondylitis. Br J Rheumatol 36: 400-401, 1997. 